\title{
Whole-body diffusion-weighted imaging for staging lymphoma: are apparent diffusion coefficient derived histogram parameters useful for lesion characterisation?
}

\author{
K De Paepe ${ }^{*}$, F De Keyzer, P Wolter, O Bechter, A Janssens, D Dierickx, R Oyen, G Verhoef, V Vandecaveye \\ From International Cancer Imaging Society (ICIS) 14th Annual Teaching Course \\ Heidelberg, Germany. 9-11 October 2014
}

\section{Aim}

To evaluate apparent diffusion coefficient (ADC) derived histogram parameters for lesion characterization in whole-body diffusion-weighted imaging (WB-DWI) of lymphoma.

\section{Methods}

Fifteen patients with histopathology proven lymphoma (11 Non-Hodgkin; 4 Hodgkin lymphomas) underwent WB-DWI using $2 \mathrm{~b}$-values $\left(0-1000 \mathrm{~s} / \mathrm{mm}^{2}\right)$. On coronal reformatted b1000 WB-DWI images, regions of interest (ROI) were drawn semi-automatically on lymph nodes in all nodal stations $(\mathrm{n}=267)$ and in axial and appendicular bone regions $(n=53)$. For each ROI, a histogram was constructed from which volume, mean $\mathrm{ADC}_{(\mathrm{ADC})}$, median $(\mathrm{ADC})$, skewness $(\mathrm{ADC})$, and kurtosis $\mathrm{ADC}_{(\mathrm{AD})}$ were calculated. Mann-Whitney-U tests were performed to detect significant differences between malignant and benign ROIs per tissue type. Receiver-operating-characteristic curves (ROC) were constructed from which an optimal threshold was determined as well as sensitivity, specificity and accuracy. PET/CT plus bone marrow biopsy (BMB) served as reference standard.

\section{Results}

All parameters were significantly different between malignant and benign lymph nodes $(\mathrm{p}<0.001)$ with skewness $_{(\mathrm{ADC})}$ being the most accurate. A positive skewness exceeding $0.3041 \mathrm{~mm}^{2} / \mathrm{s}$ allowed for detection of malignant lymph nodes with $88 \%$ accuracy, $88 \%$ sensitivity and $87 \%$ specificity compared to $63 \%$ accuracy, $61 \%$ sensitivity and $64 \%$ specificity for mean $\operatorname{maDC}_{(\mathrm{ADC})}$. Only kurtosis $_{(\mathrm{ADC})}(\mathrm{p}<0.001)$ and skewness $(\mathrm{ADC})(\mathrm{p}=0.003)$ were significantly different between malignant bone marrow infiltration and normal bone marrow. Kurtosis(ADC) showed highest accuracy and a threshold exceeding 5.26 allowed for detection of malignant bone marrow infiltration with $89 \%$ accuracy, $86 \%$ sensitivity and $90 \%$ specificity.

\section{Conclusions}

ADC histogram analysis is feasible for lesion characterization in WB-DWI of lymphoma. Lymph nodes were most accurately characterized using skewness $(\mathrm{ADC})$ and bone tissue using kurtosis $(\mathrm{ADC})$.

Published: 9 October 2014

\section{doi:10.1186/1470-7330-14-S1-S9}

Cite this article as: De Paepe et al:: Whole-body diffusion-weighted imaging for staging lymphoma: are apparent diffusion coefficient derived histogram parameters useful for lesion characterisation? Cancer Imaging 2014 14(Suppl 1):S9.

* Correspondence: katja.depaepe@uzleuven.be University Hospitals Leuven, Leuven, Belgium

(c) 2014 De Paepe et al; licensee BioMed Central Ltd. This is an Open Access article distributed under the terms of the Creative Commons Attribution License (http://creativecommons.org/licenses/by/4.0), which permits unrestricted use, distribution, and reproduction in any medium, provided the original work is properly cited. The Creative Commons Public Domain Dedication waiver (http://creativecommons.org/publicdomain/zero/1.0/) applies to the data made available in this article, unless otherwise stated. 